\title{
In Vitro Studies on Alpha-amylase Inhibitory Activities of Zanthoxylum armatum of Mid-Western Regions of Nepal
}

\author{
Deepak Dahal ${ }^{*}$, Anup Subede ${ }^{2}$, Kalpana Khanal ${ }^{3}$, Ram Chandra Basnyat ${ }^{{ }^{*}}$ \\ ${ }^{1}$ Central Department of Chemistry, Tribhuvan University, Kathmandu, Nepal \\ ${ }^{2}$ Department of Chemistry, Amrit Campus, Tribhuvan University, Kathmandu, Nepal \\ ${ }^{3}$ Department of Chemistry, Tri-Chandra Multiple Campus, Tribhuvan University, Kathmandu, Nepal \\ *E-mail: dahaldeepak2014@gmail.com; basnyatram@gmail.com
}

(Received:27 March 2021, Received in revised form: 22 April, Accepted: 15 June 2021, Available Online)

\section{Highlights}

- The fruits, seeds, leaves, and barks of Zanthoxylum armatum were collected from Karnali province of Nepal.

- $\alpha$-amylase inhibition activity was performed for both methanol extract and hexane extract.

- Chemical constituents present in different extracts of $Z$. armatum can be used as a medicine for hyperglycemic patient.

\begin{abstract}
The alpha-amylase inhibitors are used as a drug to control hyperglycemia in type II diabetes mellitus. The plant extract is a natural source to minimize toxicity and other side effects. The alpha-amylase inhibition assay shows that the methanol extracts of fruits, seeds, leaves, and barks of Z. armatum exhibit 50\% alpha-amylase inhibition activity at concentration $47.73 \mu \mathrm{g} / \mathrm{mL}, 50.25$ $\mu \mathrm{g} / \mathrm{mL}, 67.25 \mu \mathrm{g} / \mathrm{mL}, 152.6 \mu \mathrm{g} / \mathrm{mL}$ respectively, and hexane extracts of fruits, seeds, leaves and barks of Z. armatum exhibits $50 \%$ alpha-amylase inhibition activity at concentration $86.24 \mu \mathrm{g} / \mathrm{mL}, 84.02 \mu \mathrm{g} / \mathrm{mL}, 98.8 \mu \mathrm{g} / \mathrm{mL}, 138.81 \mu \mathrm{g} / \mathrm{mL}$ respectively, whereas the 50\% alpha-amylase inhibition activity of Acarbose (standard) was found to be $33.66 \mu \mathrm{g} / \mathrm{mL}$. Therefore, methanol and hexane extracts of fruits, seeds, and leaves show potential alpha-amylase inhibition activity and can be used as anti-diabetes.
\end{abstract}

Keywords: Alpha-amylase, Antidiabetes, $I_{50}$, Inhibitory, Type I DM, and type II DM

\section{Introduction}

Diabetes mellitus has emerged as a major health problem in both developed and developing countries. It is a chronic endocrine metabolic disorder characterized by altered carbohydrates, lipids, proteins, electrolytes, and water metabolism. It includes a group of metabolic diseases characterized by hyperglycemia, in which blood sugar levels are raised either because the pancreas does not produce enough insulin or cells do not respond to the produced insulin [1]. Hyperglycemia and hyperlipidemia are two important characteristics of diabetes mellitus, an endocrine disorder-based disease. The development of a novel technique that can improve glycemic management and even cure diabetes mellitus is of great study [2]. It is a global health burden and the incidence of diabetes among the global population is increasing every year. It has been estimated that 171 million of the world population were affected by diabetes in the year 2000, 285 million in 2010, 366 million in 2011, 382 million in 2013, 415 million in 2015, and 451 million in $2017[3]$.

There are three main types of diabetes mellitus according to World Health Organization (WHO)

- $\quad$ Type I DM: It results from the pancreas's failure to produce enough insulin and is also known as "insulin-dependent diabetes mellitus" (IDDM) or "juvenile diabetes".

${ }^{*}$ Corresponding author 
- Type II DM: It begins with insulin resistance, a condition in which cells fail to respond to insulin properly. As the disease progresses a lack of insulin may also develop and this form is also known as "non-insulin-dependent diabetes mellitus" (NIDDM) or "adult-onset diabetes". The primary cause is excessive body weight and not enough exercise.

- Gestational Diabetes: It is the third form and occurs when pregnant women without a previous history of diabetes develop high blood sugar levels. The embryos exposed to high glucose show changes in cell proliferation, migration, and differentiation during corticogenesis [4].

Type I DM must be managed with insulin injections, type II DM may be treated with medications with or without insulin and Gestational Diabetes usually resolves after the birth of the baby (WHO).

Uncontrolled diabetes is manifested by a very high rise in triglycerides and fatty acid levels[5]. Epidemiological studies and clinical trials support that hyperglycemia is the major cause of complications related to coronary artery disease, myocardial infarction, cerebrovascular disease, renal failure, hypertension, blindness, limb amputation, neurological complications, and premature death[6], [7]. It affects all age groups worldwide. The chronic hyperglycemia of diabetes is associated with relatively specific long-term microvascular complications affecting the heart, eyes, kidneys, and nerves, as well as an increased risk for cardiovascular disease (CVD) [8]. Therefore, a drug having twofold properties, that is, lowering of blood lipids (triglycerides and cholesterol) and glucose together is in great demand [9].

The intestinal $\alpha$-amylase is involved in the breakdown of long-chain carbohydrates and $\alpha$-glucosidase breaks down starch and disaccharides to glucose. By inhibiting the action of these enzymes (insulin-like activity), type II DM can be reduced. Higher plants, animals, and microorganisms are found to produce a large number of different protein inhibitors of carbohydrate hydrolyzing enzymes ( $\alpha$-amylases and $\alpha$-glucosidases) [10]. Plant food rich in polyphenols have been reported to cause effects similar to insulin in the utilization of glucose and act as good inhibitors of enzymes like $\alpha$-amylase and $\alpha$ - glucosidase. Acarbose and miglitol are competitive inhibitors of intestinal $\alpha$-glucosidases and reduce the post-prandial digestion and absorption of starch and disaccharides without promoting insulin secretion in DM patients [11]. The $\alpha$-glucosidase inhibitors are used as oral anti-diabetic drugs for treating type II DM [12].

Worldwide, presently used synthetic enzyme inhibitors cause gastrointestinal side effects such as diarrhea, flatulence, abdominal bloating, etc [13]. Therefore natural $\alpha$-amylase and $\alpha$-glucosidase inhibitors from the dietary plants can be used as an effective therapy for treating post prandial hyperglycemia with minimum side effects [14]. During the second half of the 19th century, a time referred to by some authors as the "alkaloid period" those agents were the most used to cure various diseases. These were introduced into psychiatric care after the isolation of morphine from opium in 1805 by Friedrich Wilhelm Sertürner [15]. In this connection, herbal medicines have long been effectively used in treating diabetes in Asian communities including Nepal and throughout the world. Natural products have received considerable attention for the management of diabetes and its complications, which have reached epidemic levels worldwide. The World Health Organization Expert Committee on diabetes also recommended that traditional medicinal plants be further investigated as they are frequently considered to be free from toxic and side effects [16]. Many of the ingredients of cooking have been containing various medicinal values and a vast ethnobotanical knowledge exists from ancient times [14].

Plants, animals, and microorganisms can produce a large number of protein inhibitors to regulate the activities of alphaamylase and alpha-glucosidase [7]. Most of these enzyme inhibitors can bind the active sides of the enzyme [17]. In herbal medicinal practice, many plants are used to treat diabetes mellitus in Nepal. Most of these medicinal plants are not scientifically validated for their efficiency and safety [5]. The alpha-amylase inhibitor helps to decrease the high glucose level in animals by slowing the speed of the conversion of starch into simple glucose [18]. This is important to balance the blood glucose level in diabetic people. Hence, lowering the active alpha-amylase to control the glucose level. Plants also used the alpha-amylase inhibitor as a defense mechanism from insects, these inhibitors affect the alpha-amylase activity at the gut of insects and inhibit their normal feeding behavior. Therefore, the alpha-amylase inhibitor has potential uses in controlling blood sugar levels in animals and increase crop production in plants [19], [20]. The overall goal of this study is to screen the selected plants for new digestion and adsorption inhibitors of aamylase inhibitors, using in vitro assays, which may offer a new therapeutic approach in the management of these diseases.

Natural products and their derivatives have been the source of bioactive molecules in medicines much before the advancement 
of other modern medicine. Several studies conducted in several countries reported that some of the population who are affected with diabetes, use complementary and alternative medicine to control the unhealthy condition [21]

several medicinal plants and some compounds purified from them have been studied for the treatment of diabetes throughout the world as they might provide a new idea for the development of new medicine with greater efficiency. [21]. Plants that have been shown to have hypoglycemic action, act on blood glucose through different mechanisms. Some of them may inhibit endogenous glucose production [21] or interfere with gastrointestinal glucose absorption [21] and some may have insulin-like substances [21]. World ethnobotanical information about medicinal plants reports almost 800 plants are used in the control of diabetes mellitus [221]. Much study and research are needed to explore such plants and constituents for the development of new alternative medicines to control or treat diabetes.

Zanthoxylum armatum is a small tree with a strong pungent and aromatic smell. Its local name is Timur in Nepali. . The seeds and bark are used as an aromatic tonic in fever, dyspepsia, and cholera. The fruit as well as branches and thorn are used as a remedy for toothache, also for stomach aches. Various parts of this Z. armatum are used in the preparation of tooth powder, toothpaste, cosmetic products, Ayurveda medicine, and ethnomedicine. The various studies of different parts of this plant show that the plants contain various useful pharmacological active compounds which help to lower the sugar level in type II diabetic patients. [21].

Evidence is available where $Z$. armatum leaves water extract was tested for anti-diabetic properties in animals. Where experiments demonstrated that Z. armatum water extract possesses anti-diabetic activity.[22]. Similarly, in another experiment, the hydromethanolic extract of bark of $Z$. armatum was evaluated for its antidiabetic activity in streptozocin-induced diabetes in rats. The total cholesterol, triglycerides, low-density lipoprotein, very low-density lipoprotein were also monitored [22]. So, there is enough evidence available for testing $Z$. armatum for an anti-diabetic property. The importance of this plant in the management of diabetes needs further investigation and help to find the effectiveness of $Z$. armatum against diabetes.

\section{Materials and Methods}

The fruits, seeds, leaves, and barks of Zanthoxylum armatum (Prickly ash) were collected in the month of Baisakh (April, May) from Rukum and Salyan districts of, Karnali Pradesh Nepal.

Extraction of plant materials

The fruits, seeds, leaves, and barks of Zanthoxylum armatum (Prickly ash)(the plant was authenticated at the Central Department of Botany, Kirtipur, Kathmandu, Nepal) were washed with distilled water and shade dried. The crude extract was extracted by taking $100 \mathrm{~g}$ of dried plant powder in $500 \mathrm{~mL}$ hexane and methanol solvents separately for 72 hours extracts were further concentrated by rotatory evaporator at $40-50^{\circ} \mathrm{C}$ and stored at $0-4^{\circ} \mathrm{C}$ for further use.

\section{Determination of alpha-amylase inhibitor activity: $\alpha$-Amylase Enzyme Inhibition Assay}

In this method, the Inhibition of $\alpha$-amylase enzyme that plays a role in the digestion of starch and glycogen is considered a strategy for the treatment of disorders in carbohydrate uptakes, such as diabetes and obesity, as well as, dental caries and periodontal diseases [19]. Starch is used as a substrate. $\alpha$ - Amylase enzyme converts starch into sugars. But acarbose (a drug used for diabetes mellitus) inhibits the action of $\alpha$-amylase and hence decreases or stops the conversion of starch. The plant extracts whose antidiabetic activities are to be examined must have the same property as acarbose i.e. they should retard or inhibit the activity of the $\alpha$-amylase enzyme.

Starch forms blue colored starch-iodine complex $\left(\lambda_{\max }=630 \mathrm{~nm}\right)$ with iodine. $\alpha$-amylase converts starch into sugars decreasing the residual starch and absorbance value will be low when iodine solution is added. But if acarbose (standard) or plant extract having antidiabetic activity is added, it inhibits the action of $\alpha$-amylase, less starch is converted into sugars and hence absorbance value will be high on adding iodine solution. On increasing the concentration of acarbose or plant extract, its inhibitory activity also increases increasing the absorbance value. 
From the absorbance value, the $\%$ inhibition of $\alpha$-amylase is calculated to determine the antidiabetic activity of extracts.[1]

The percentage inhibition of $\alpha$-amylase is calculated as follows:

Percentage $\alpha$ - amylase inhibition $=\left(1-\frac{A_{1}-A_{2}}{A_{0}-A_{2}}\right) \times 100 \%$

Where,

$\mathrm{A}_{1}=$ Absorbance of $($ Starch + Extract/Acarbose + Enzyme + Iodine $)$

$\mathrm{A}_{2}=$ Absorbance of $($ Starch + Enzyme + Iodine $)$

$\mathrm{A}_{0}=$ Absorbance of (Starch + Iodine $)$

\section{Preparation of Iodine Solution $(0.0025 \mathrm{M})$}

First of all $5 \mathrm{~g}$ potassium iodide (KI) was weighed out and $250 \mathrm{~mL} 2 \% \mathrm{KI}$ solution was prepared in a $250 \mathrm{~mL}$ volumetric flask by dissolving in distilled water. Then $100 \mathrm{~mL}$ of $2.5 \mathrm{mM}$ solution of iodine was prepared by weighing out $0.064 \mathrm{~g}$ iodine and dissolving in $2 \% \mathrm{KI}$ solution in a $100 \mathrm{~mL}$ volumetric flask.

\section{Preparation of Phosphate Buffer (0.02M)}

Sodium hydrogen phosphate $\left(\mathrm{Na}_{2} \mathrm{HPO}_{4}\right)$ crystals $(0.284 \mathrm{~g})$ were weighed out, poured into a $100 \mathrm{~mL}$ volumetric flask, dissolved, and volume was made up to the level by distilled water to make $100 \mathrm{~mL}$ of $0.02 \mathrm{M} \mathrm{Na}_{2} \mathrm{HPO}_{4}$ solution. Similarly, sodium dihydrogen phosphate $\left(\mathrm{NaH}_{2} \mathrm{PO}_{4}\right)$ crystals $(0.312 \mathrm{~g})$ were weighed out and $100 \mathrm{~mL}$ of $0.02 \mathrm{M} \mathrm{NaH}_{2} \mathrm{PO}_{4}$ solution was prepared in distilled water.

Then $50 \mathrm{~mL}$ of $0.02 \mathrm{M} \mathrm{Na}_{2} \mathrm{HPO}_{4}$ solution and $50 \mathrm{~mL}$ of $0.02 \mathrm{M} \mathrm{NaH}_{2} \mathrm{PO}_{4}$ solution were mixed and $0.0196 \mathrm{~g}(6.7 \mathrm{mM}) \mathrm{NaCl}$ was added. Finally, the $\mathrm{pH}$ of the $0.02 \mathrm{M}$ phosphate buffer was maintained at 6.9 by adding dilute $\mathrm{HCl}$ and dilute $\mathrm{NaOH}$.

\section{Preparation of Starch Solution $(2000 \mu \mathrm{g} / \mathrm{mL})$}

Starch $(200 \mathrm{mg})$ was weighed out and taken in a beaker. Then about $25 \mathrm{~mL}$ distilled water was added and the content was warmed with constant stirring to dissolve starch completely. Finally, the solution was transferred into a $100 \mathrm{~mL}$ volumetric flask and the volume was made up to the mark adding distilled water.

\section{Preparation of Stock Solution of $\alpha$-amylase Enzyme $(50 \mu \mathrm{g} / \mathrm{mL})$}

$\alpha$ - Amylase enzyme powder $(5 \mathrm{mg}$ ) was weighed out and poured into a $100 \mathrm{~mL}$ volumetric flask. About $25 \mathrm{~mL}$ phosphate buffer was added into the flask and the enzyme was dissolved completely. Finally, the volume was made up to the mark by adding phosphate buffer.

\section{Preparation of Stock Solution of Extracts or Acarbose}

Different plant extracts ( $2 \mathrm{mg}$ ) were weighed out and dissolved in $2 \mathrm{~mL}$ DMSO (dimethyl sulfoxide) to prepare $1000 \mu \mathrm{g} / \mathrm{mL}$ stock solution of extracts. Then extract solutions having $20,40,80,160,320$, and $640 \mu \mathrm{g} / \mathrm{mL}$ were prepared by serial dilution from a stock solution. Finally, these solutions prepared in test tubes were labeled and stored until further use. Following the same procedure above, acarbose solutions having different concentrations were prepared and stored until further use.

\section{Preparation of 0.1 M HCl Solution}

The concentrated $\mathrm{HCl}$ available in the laboratory was $11.66 \mathrm{M}$. Thus, $0.9 \mathrm{~mL}$ conc. $\mathrm{HCl}$ was pipetted out and $100 \mathrm{~mL}$ solution was prepared by adding distilled water in a volumetric flask.

\section{Measurement of Enzyme inhibition Activity}

First of all, $400 \mu \mathrm{L}(2000 \mu \mathrm{g} / \mathrm{mL})$ starch solution was pipetted out into a clean and dry test tube and incubated at $37{ }^{\circ} \mathrm{C}$ for 5 minutes. Then, $200 \mu \mathrm{L}$ extract/acarbose solution was added and incubated at $37^{\circ} \mathrm{C}$ for 5 minutes. After 5 minutes, $200 \mu \mathrm{L}(50$ $\mu \mathrm{g} / \mathrm{mL}) \alpha$-amylase enzyme solution was added and again incubated at $37^{\circ} \mathrm{C}$ for 5 minutes. After 15 minutes, $80 \mu \mathrm{L}(0.1 \mathrm{M}) \mathrm{HCl}$ solution was added to quench the reaction and $1000 \mu \mathrm{L}(0.0025 \mathrm{M})$ iodine solution was added as a coloring agent. Finally, the absorbance (spectrophotometer of CDC Kirtipur) was measured as $\mathrm{A}_{1}$. 
The absorbance of $400 \mu \mathrm{L}$ starch solution and $1000 \mu \mathrm{L}$ iodine solution was measured as $\mathrm{A}_{0}$. At the same time, the absorbance of $400 \mu \mathrm{L}$ starch, $200 \mu \mathrm{L} \alpha$-amylase enzyme solution, and $1000 \mu \mathrm{L}$ iodine solution was measured as $\mathrm{A}_{2}$.

\section{Results and Discussion}

The percentage $\alpha$-amylase inhibition value was calculated and the $\mathrm{IC}_{50}$ values of different samples were calculated by using graphs.

Table 1. Percentage alpha amylase inhibition and $I C_{50}$ values of different samples

\begin{tabular}{|c|c|c|c|c|c|c|c|c|}
\hline $\begin{array}{l}\text { Concentration } \\
\qquad(\mu \mathrm{g} / \mathrm{mL})\end{array}$ & $\begin{array}{l}\% \text { alpha } \\
\text { amylase } \\
\text { inhibition } \\
\text { of } \\
\text { acarbose }\end{array}$ & $\begin{array}{c}\mathrm{IC}_{50}(\mu \mathrm{g} / \\
\mathrm{mL})\end{array}$ & $\begin{array}{l}\text { Concentration } \\
\qquad(\mu \mathrm{g} / \mathrm{mL})\end{array}$ & $\begin{array}{c}\% \text { alpha } \\
\text { amylase } \\
\text { inhibition } \\
\text { of } \mathrm{MF}\end{array}$ & $\begin{array}{c}\mathrm{IC}_{50} \\
(\mu \mathrm{g} / \mathrm{mL})\end{array}$ & $\begin{array}{l}\text { Concentration } \\
\qquad(\mu \mathrm{g} / \mathrm{mL})\end{array}$ & $\begin{array}{c}\% \text { alpha } \\
\text { amylase } \\
\text { inhibition } \\
\text { of } \mathrm{HF}\end{array}$ & $\begin{array}{c}\mathrm{IC}_{50} \\
(\mu \mathrm{g} / \mathrm{mL})\end{array}$ \\
\hline 0 & 0.00 & & 0 & 0.00 & & 0 & 0.00 & \\
\hline 20 & 52.90 & & 20 & 31.64 & & 20 & 41.30 & \\
\hline 40 & 58.94 & 81.18 & 40 & 37.44 & 94.68 & 40 & 47.34 & 97.13 \\
\hline 80 & 64.98 & & 80 & 51.93 & & 80 & 57.73 & \\
\hline 160 & 77.05 & & 160 & 72.95 & & 160 & 63.53 & \\
\hline
\end{tabular}

\begin{tabular}{|c|c|c|c|c|c|c|c|c|}
\hline $\begin{array}{l}\text { Concentration } \\
\qquad(\mu \mathrm{g} / \mathrm{mL})\end{array}$ & $\begin{array}{c}\% \text { alpha } \\
\text { amylase } \\
\text { inhibition } \\
\text { of MS }\end{array}$ & $\begin{array}{c}\mathrm{IC}_{50} \\
(\mu \mathrm{g} / \mathrm{mL})\end{array}$ & $\begin{array}{c}\text { Concentration } \\
(\mu \mathrm{g} / \mathrm{mL})\end{array}$ & $\begin{array}{c}\% \text { alpha } \\
\text { amylase } \\
\text { inhibition } \\
\text { of HS }\end{array}$ & $\begin{array}{c}\mathrm{IC}_{50} \\
(\mu \mathrm{g} / \mathrm{mL})\end{array}$ & $\begin{array}{l}\text { Concentration } \\
(\mu \mathrm{g} / \mathrm{mL})\end{array}$ & $\begin{array}{c}\% \text { alpha } \\
\text { amylase } \\
\text { inhibition } \\
\text { of ML }\end{array}$ & $\begin{array}{c}\mathrm{IC}_{50} \\
(\mu \mathrm{g} / \mathrm{mL})\end{array}$ \\
\hline 0 & 0.00 & & 0 & 0.00 & & 0 & 0.00 & \\
\hline 20 & 19.32 & & 20 & 20.77 & & 20 & 19.56 & \\
\hline 40 & 35.51 & 106.84 & 40 & 33.82 & 120.92 & 40 & 30.92 & 111.03 \\
\hline 80 & 51.21 & & 80 & 41.55 & & 80 & 43.96 & \\
\hline 160 & 62.56 & & 160 & 56.04 & & 160 & 63.53 & \\
\hline
\end{tabular}

\begin{tabular}{|c|c|c|c|c|c|c|c|c|}
\hline $\begin{array}{l}\text { Concentration } \\
\qquad(\mu \mathrm{g} / \mathrm{mL})\end{array}$ & $\begin{array}{c}\% \text { alpha } \\
\text { amylase } \\
\text { inhibition } \\
\text { of HL }\end{array}$ & $\begin{array}{c}\mathrm{IC}_{50} \\
(\mu \mathrm{g} / \mathrm{mL})\end{array}$ & $\begin{array}{c}\text { Concentration } \\
(\mu \mathrm{g} / \mathrm{mL})\end{array}$ & $\begin{array}{c}\% \text { alpha } \\
\text { amylase } \\
\text { inhibition } \\
\text { of } \mathrm{MB}\end{array}$ & $\begin{array}{c}\mathrm{IC}_{50} \\
(\mu \mathrm{g} / \mathrm{mL})\end{array}$ & $\begin{array}{l}\text { Concentration } \\
(\mu \mathrm{g} / \mathrm{mL})\end{array}$ & $\begin{array}{c}\% \text { alpha } \\
\text { amylase } \\
\text { inhibition } \\
\text { of HB }\end{array}$ & $\begin{array}{c}\mathrm{IC}_{50} \\
(\mu \mathrm{g} / \mathrm{mL})\end{array}$ \\
\hline 0 & 0.0 & & 0 & 0.00 & & 0 & 0.00 & \\
\hline 20 & 28.26 & & 20 & 24.64 & & 20 & 32.13 & \\
\hline 40 & 43.24 & 92.44 & 40 & 34.54 & 105.48 & 40 & 43.96 & 94.37 \\
\hline 80 & 61.11 & & 80 & 50.48 & & 80 & 56.52 & \\
\hline 160 & 70.05 & & 160 & 63.77 & & 160 & 69.32 & \\
\hline
\end{tabular}

Here, $\mathrm{MF}=$ Methanol extract of Fruits

$$
\begin{aligned}
& \mathrm{MS}=\text { Methanol extract of Seeds } \\
& \mathrm{ML}=\text { Methanol extract of Leaves } \\
& \mathrm{MB}=\text { Methanol extract of Barks } \\
& \mathrm{HF}=\text { Hexane extract of Fruits }
\end{aligned}
$$


HS $=$ Hexane extract of Seeds

$\mathrm{HL}=$ Hexane extract of Leaves

$\mathrm{HB}=$ Hexane extract of Barks

Percentage $\alpha$-amylase inhibition versus concentration curves is plotted. Thus obtained percentage $\alpha$-amylase inhibition versus concentration curves for acarbose (standard) and different plant extracts were shown in the following plots.

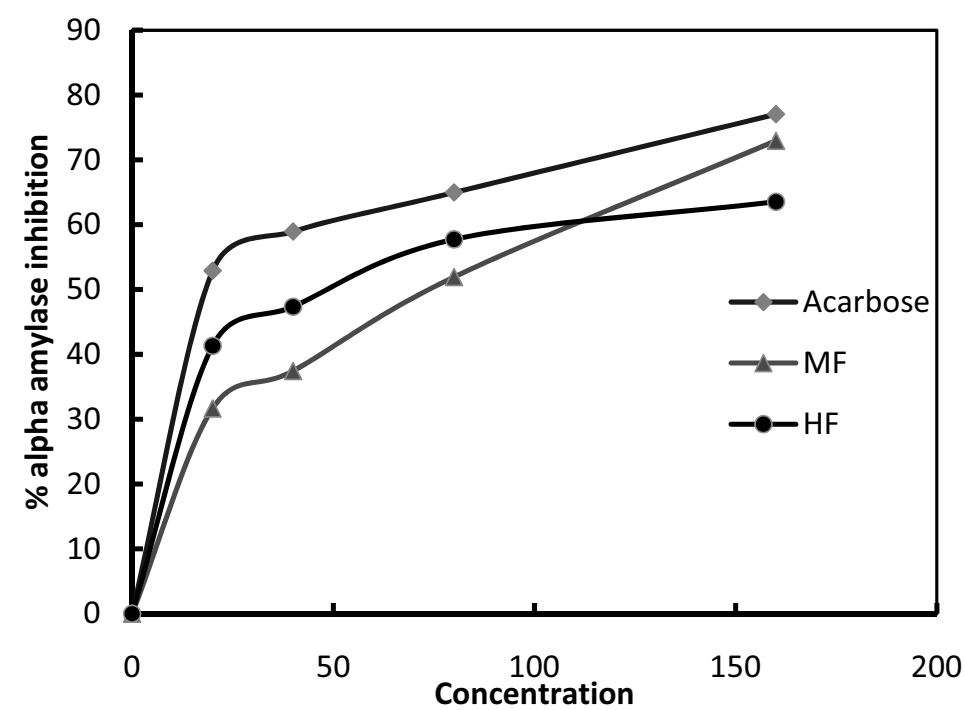

Fig 1: Percentage $\alpha$-amylase Inhibition vs. Concentration $(\mu \mathrm{g} / \mathrm{mL})$ Curve for methanol and hexane extracts of fruits of $Z$. armatum and acarbose.

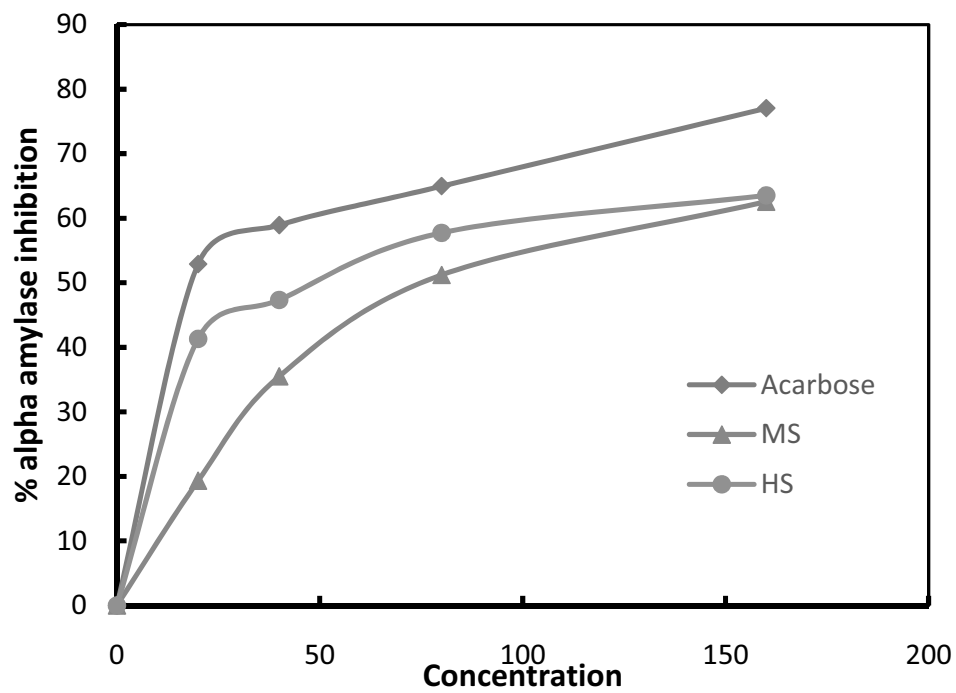

Fig 2: Percentage $\alpha$-amylase Inhibition vs. Concentration Curve for methanol and hexane extracts of seeds of Z. armatum and acarbose. 


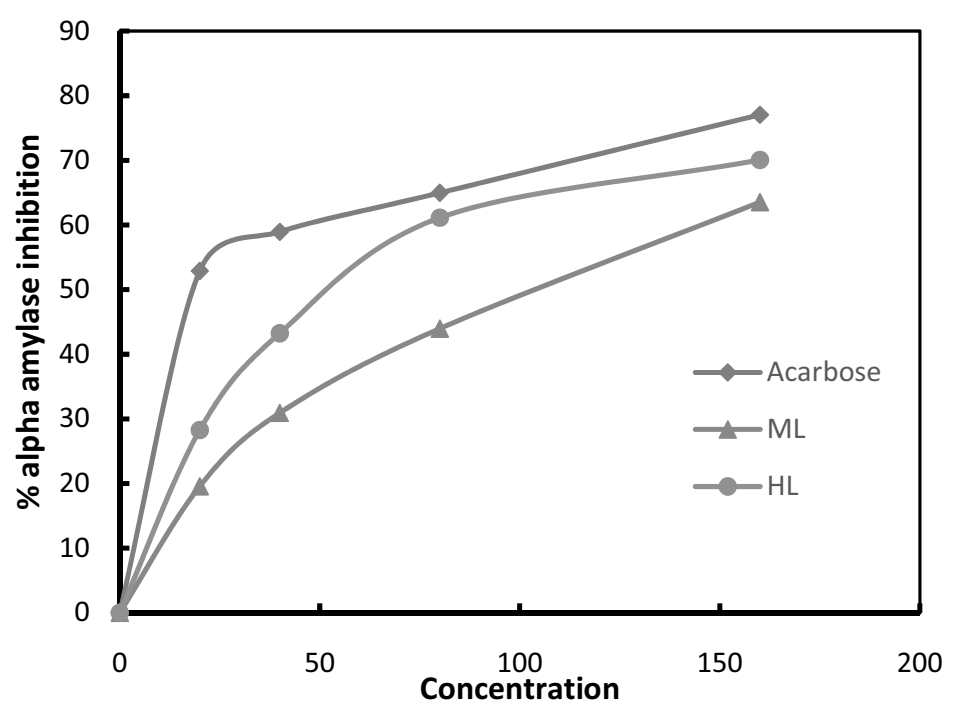

Fig 3: Percentage $\alpha$-amylase Inhibition vs. Concentration Curve for methanol and hexane extract of leaves of Z. armatum and acarbose.

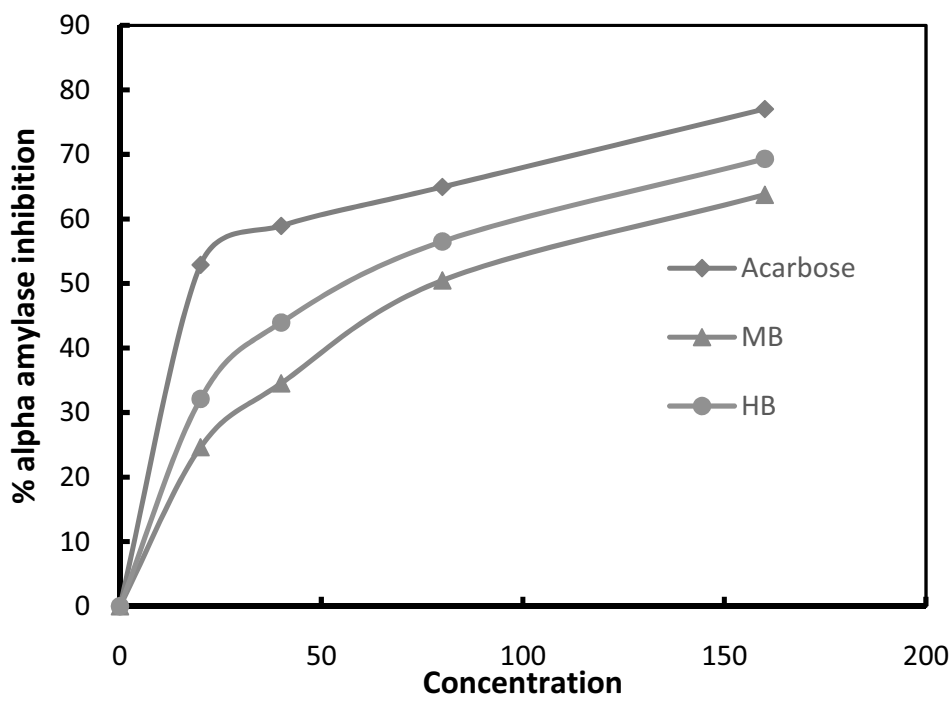

Fig 4: Percentage $\alpha$-amylase Inhibition vs. Concentration Curve for methanol and hexane extract of barks of Z. armatum and acarbose.

Different parts of Timur such as fruits, seeds, leaves, and barks are used as traditional medicines by local people of Midwestern parts of Nepal. The enzyme $\alpha$ - amylase is decomposed starch into glucose molecules and increases the glucose level in our body. To reduce the blood glucose level the $\alpha$ - amylase activity should inhibit any way. The in vitro $\alpha$ - amylase inhibition assay elucidate the potent enzyme inhibitory activity of Methanol and Hexane extract of plant parts, which is compared with the standard drug acarbose recommended for the diabetic patient.

The $\alpha$-amylase inhibition activity of extract with different concentration compared with acarbose as a standard where the $\mathrm{IC}_{50}$ values of acarbose is found to be $81.18 \mu \mathrm{g} / \mathrm{mL}$, and $\mathrm{IC}_{50}$ of methanol extracts of fruits, seeds, leaves, and barks is $94.68 \mu \mathrm{g} /$ $\mathrm{mL}, 106.84 \mu \mathrm{g} / \mathrm{mL}, 111.03 \mu \mathrm{g} / \mathrm{mL}$ and $105.48 \mu \mathrm{g} / \mathrm{mL}$ respectively. The $\mathrm{IC}_{50}$ values of hexane extract of fruits, seeds, leaves, and barks is found to be $97.13 \mu \mathrm{g} / \mathrm{mL}, 120.92 \mu \mathrm{g} / \mathrm{mL}, 92.44 \mu \mathrm{g} / \mathrm{mL}$, and $94.37 \mu \mathrm{g} / \mathrm{mL}$ respectively. The Methanol and Hexane extract of fruits shows comparable $\alpha$-amylase inhibition as that of acarbose (Recommended standard drug). Thus in this way, the in vitro $\alpha$ - amylase inhibition assay was studied.

Thus, the chemical constituents present in different parts of $Z$. armatum are responsible for the $\alpha$ - amylase inhibition activity. 


\section{Conclusions}

This study concludes that the methanol extracts of fruits, seeds, leaves, and barks of Z. armatum (Timur) show $\alpha$ - amylase inhibition activity, which could justify the ethnomedical importance used traditionally in Nepal from a long time ago. The use of this medicine helps to treat type II diabetes (Madhumeha). The chemical constituents present in different extracts of Z. armatum show alpha-amylase enzyme inhibition activity and can be used as a medicine for the hyperglycemic patient (Anti Diabetic). This fact highly supports the use of Timur in the traditional medicine system as well as ayurvedic medicines.

\section{Acknowledgments}

Authors are grateful to the Central Department of Chemistry, Kirtipur, Kathmandu, Nepal for laboratory support.

\section{References}

1. S.S. Nair, V. Kavrekar, A. Mishra. In vitro studies on alpha-amylase and alpha-glucosidase inhibitory activities of selected plant extracts, European Journal of Experimental Biology, 2013, 3(1), 128-132.

2. G. Kanchana, W. J. Shyni, M. Rajadurai, R. Periasamy. Evaluation of Antihyperglycemic Effect of Sinapic Acid in Normal and Streptozotocin-Induced Diabetes in Albino Rats, Global Journal of Pharmacology, 2011, 5(1), 33-39.

3. N. Mohamed, P. Maideen, R. Balasubramaniam. Pharmacologically relevant drug interactions of sulfonylurea antidiabetics with common herbs, Journal of Herbmed Pharmacology, 2018, 7(3), 200-210, (Doi: 10.15171/jhp.2018.32).

4. R. Valle-bautista, B. Márquez-valadez, A.D. Fragoso-cabrera, G.García-lópez, N.F.Díaz, G.Herrera-lópez. Impaired Cortical Cytoarchitecture and Reduced Excitability of Deep-Layer Neurons in the Offspring of Diabetic Rats, Frontiers in cell and development biology, 2020, 8, 1-18, (Doi: 10.3389/fcell.2020.564561).

5. S. Antonio. Hyperinsulinaemia: the key feature of a cardiovascular and metabolic syndrome, Diabetologia, Texas USA, 1991, 416-422,

6. P. Liu, T. Cheng. Improvement of Insulin Resistance by Panax Ginseng in Fructose - rich Chow - fed Rats," Original Clinical, 2005, 146-151, (Doi: 10.1055/s).

7. To. C and O Publications, Methods and compositions to reduce fat gain, promote weight loss in animal”, United States Patent (45),2019(12).

8. V. Korthikunta, P. Pandey, P. Singh, R. Srivastava. Phytomedicine In vitro anti-hyperglycemic activity of 4-hydroxyisoleucine derivatives, Europian Journal of Integrative Medicine, 2015, 22(1), 66-70, (Doi: 10.1016/j. phymed.2014.09.007).

9. T. Narender., et al. Antihyperglycemic and antidyslipidemic agent from Aegle marmelos, Bioorganic \& Medicinal Chemistry Letters, 2007, 17, 1808-1811, (Doi: 10.1016/j.bmcl.2006.12.037).

10. K.R. Biswas, et al. A Review of Scientific Literature on Anti-diabetic Activity in Medicinal Plants Used by Folk Medicinal Practitioners of Two Villages in Narail and Chuadanga districts, Bangladesh for Treatment of Diabetes, American-Eurasian Journal of Sustainable Agriculture, 2001, 5(78), 196-208.

11. S. Christudas, L. Gopalakrishnan, P. Mohanraj. $\alpha$-Glucosidase inhibitory and antidiabetic activities of ethanolic extract of Pisonia alba Span. leaves Effect of PAEE on Oral Glucose Tolerance Test (OGTT), International Journal of Integrative Biology, 2009, 6(1).

12. D.R. Chhetri, P. Parajuli, G.C. Subba, Antidiabetic plants used by Sikkim and Darjeeling Himalayan tribes, India, Journal of Ethnopharmacology, 2005, 99,199-202, (Doi: 10.1016/j.jep.2005.01.058).

13. G.A. Bray, F.L. Greenway, Current and Potential Drugs for Treatment of Obesity, Endocrine Reviews, $2014,20,805-875$. 
14. U. Chakraborty. Antidiabetic and Antioxidant Activities of Cinnamomum Tamala Leaf Extracts in STZ-Treated Diabetic Rats Antidiabetic and Antioxidant Activities of Cinnamomum Tamala Leaf Extracts in Stz-Treated Diabetic Rats. Global Journal of Biotechnology \& Biochemistry,2015

15. A. Francisco, A. Cecilio. A History of the Pharmacological Treatment of Bipolar Disorder," International Journal of molecular sciences, 2018, 1-38, (Doi: 10.3390/ijms19072143)

16. G. Smruthi, V. Mahadevan, S. Sahayam. Anti-Diabetic Potential of Selected Indian Traditional Medicinal Plants. Journal of pharmaceutical sciences and research, 2016, 1(8).

17. A. Parvin, M. Alam, A. Haque, A. Bhowmik, L. Ali, B. Rokeya. Study of the Hypoglycemic Effect of Tamarindus indica Linn. Seeds on Non-Diabetic and Diabetic Model Rats, British Journal of Pharmaceutical Research, 2013, 3(4), 1094-1105.

18. G.C.H.D. Nagalakshmi, S.S. Rao, G. Fareeda, Hypoglycemic effect Of Aqueous fruit extract of ficus bengalensis in normal and streptozotocin-induced diabetic rats, The bioscan, 2010, 5(2), 197-200.

19. P.M. De Sales, P.M. De Souza, L.A. Simeoni, P.D.O. Magalhães, $\alpha$-Amylase Inhibitors: A Review of Raw Material and Isolated Compounds from Plant Source, Journal of Pharmacy and Pharmaceutical Science, 2012, 15(1),141-183.

20. R. Kumanan, S. Manimaran, K. Saleemulla, S.P.Dhanabal, M.J. Nanjan,(Screening of bark of Cinnamomum Tamala ( Lauraceae ) by using $\alpha$-amylase inhibition assay for anti-diabetic activity, International Journal of pharmaceutical and biomedical research .2015 ,

21. C.V. Rynjah, N.N. Devi, N. Khongthaw, D. Syiem, S. Majaw, Evaluation of the antidiabetic property of aqueous leaves extract of Zanthoxylum armatum DC. Using in vivo and in vitro approaches. Journal of traditional and complementary medicine, 2018, 8(1),134-140.

22. H. Karki, K. Upadhayay, H. Pal, R. Singh. Antidiabetic potential of Zanthoxylum armatum bark extract on streptozotocininduced diabetic rats, International Journal of Green Pharmacy, 2014, 8(2) 77. 